\title{
Lapurdum
}

LAPURDUM Euskal ikerketen aldizkaria | Revue d'études basques |

Revista de estudios vascos | Basque studies review

$8 \mid 2003$

Numéro VIII

\section{Artzeren poesiaren pentsakizunaz}

Jon Kortazar

URL : http://journals.openedition.org/lapurdum/1146

DOI : 10.4000/lapurdum. 1146

ISSN : 1965-0655

Éditeur

IKER

Édition imprimée

Date de publication : 1 novembre 2003

Pagination : 285-328

ISBN : 9782867813436

ISSN : $1273-3830$

\section{Référence électronique}

Jon Kortazar, «Artzeren poesiaren pentsakizunaz », Lapurdum [Linean], $8 \mid$ 2003, Sarean emana----an

01 mai 2009, kontsultatu 19 avril 2019. URL : http://journals.openedition.org/lapurdum/1146 ; DOI :

10.4000/lapurdum. 1146 


\section{Artzeren poesiaren pentsakizunaz}

\section{Kontrakulturaren bidetik, bide berriak bilatzen}

Idazlan berri gisa agertzen du Jose Anton Artzek. ${ }^{1}$ 1969. urtean Isturitzetik Tolosan barru poema liburua. Arte desberdin askoren koktela da liburua: poesia eta grafismoa, inprenta-lana eta pintura, musika eta poesia espaziala. Era askotako artea errealitatea den poliedroa agertzeko asmoz, espresabide bakar batek, poesiak, besarkatu ezin balu bezala.

Gizarte autoritario baten azken aztarnak jausten ari ziren, mendebaldeko kulturak krisialdia bizi zuen: Pariseko Maiatzak kolokan jarri zuen Frantziako Demokrazia, Pragako hiriak komunismo inperialistaren bidea, eta San Franciscoko talde hippy-ek eta beat-ek Vietnam-eko guda. Irakitan zegoen mundua, eta irakitan dago Artzeren liburua ere, oroimenaren eta berria nahi den mundu baten artean.

60ko urteen buruan, berdintsua zen egoera Euskal Herrian, baina, beharrezkoak dira salbuespenak egitea, azken batean. Franco jeneralaren erregimen autokratikoak mugak jartzen baitizkio marko orokor honi. López Adán-ek, adibidez, 1968-69 urteetan gertatzen den giroa marrazteko ekintza hauek azpimarratu ditu:

Parisen Maiatza, Txekoslovakian sobietarren inbasioa, Alemanian Baader talde armatuaren agerpena, Estatu Batuetan Martin Luther Kingen erailtzea, Medellinen Askapen Teologiari indar berezia eman zion Batzarra" (1996: 249).

Idazle berak, garai haietako berrikuntzaren ikur bihurtu den Rikardo Arregiren garaia aipatzerakoan honelako joera berriak aipatzen ditu:

Esperimentazio berria, budismo eta existentzialismcaren agerpenarekin.

Hazkunde ekonomikoa eta mugimendu langilearen berpiztea.

Euskararekiko kontzientzia agonikoa.

- Oteizaren itzala.

\footnotetext{
I Abizenaren ortografia oso desberdina erabili du Artzek: Arce, Arze, Artze, Hartzabal,... Denetarik Artze aukeratu dugu.
} 
Arantzazuren proiektu artistikoa.

Euskaltzaindiaren berplanteamentua euskaran ; euskara batuaren sorrera.

Vaticanoko II. kontzilioa modernitatearen bidean.

Abanguardia, Konpromezu soziala, korronte modernoen ezagutza. (López Adán 1996: 203-229)

Kontrakulturaren sintomak agertzen ditu López Adán-ek, eta, oro har, Rikardo Arregiren lanak. Baina, kontrakulturaz hitz egiterakoan, perspektiba bikoitza mantendu beharko litzateke, batetik Euskal Herrian gertatzen dena kontuan hartuz, eta, bestetik, munduan gertatzen dena kontuan hartuz. Kontrakultura mendebaldean izan zen krisialdia da. Euskal Herrikoa haren oihartzuna litzateke, gehienez ere, eta haren aldakia.

Luis Racioneroren ustetan, ekonomiaren aldaketak estutasunetik nolabaiteko aberastasunera aldatzeak, eragingo luke mendebaleko gizartearen aldaketa.

Ahalbide ekonomikoak, hazkuntza industrialak, atsedenerako, aisialdirako beta eman dio gizakiari. Hazkuntza ekonomikoa 1973. urteko petrolio krisiraino helduko da. Hazkuntza ekonomikoak ondorio soziala izango du, era berean, langileria klase ertain bihurtuko da. Baina hasiera batean ekonomiak agintzen badu, ekonomiak arazoak sortu ditu beste hainbat esparrutan. Neurri batean, bizi den giroa ez da maite Mendebaldean eta beste zerbaiten bila abiatzen da gizakia : dirua badu, baina diruak ematen ez duena bilatzen da. 70. hamarkadako kontrakultura aztertu duen Andrés López Ibarrondok (1991) alor hauetan ikusi du kontrakulturaren lana:

- Sistema kapitalaren ukazioa, sozialismoaren bideak ugaltzen direlarik, eta, harago, bien ukazioa erlazio ekonomiko diren heinean, eguneroko bizitzaren iraultza bilatzen delarik.

Gizabanakoaren nortasun krisialdia. Nitasunaren krisialdian gaude: gizakiak nabari du sistemak ito egiten duela, eta bere ahalbideak ez dituela haz bidean jartzen. Giza-balioen krisialdia ere gertatzen da eta pertsonak norabiderik gabe ikusten du bere izaera. Frommek honela idatzi zuen 1973. urtean:

[Pertsonak] gizabanako izateko, barne gogoa betetzeko, eta zuzenbiderako gogo nostalgikoa du... baina balio horiek desagertu dira, enpresa erraldoien burokrazia estatal eta militar erraldoien, eta sindikatu erraldoien munduan. 
- Giza gorputza eta sexualitatea kolokan daude, sexualitatearen askatasunarekin batera, familiak eratzeko forma berriak antolatzen dira.

- Gizarteak agertzen duen arrazionalitatearen ukazioa gertatzen da.

- Elkartasun balioa era desagertu egin da. Hurkoa ez da laguna baizik eta kontrarioa, giza-bizitzan irabazi beharreko norbait.

- Politikan parte hartzeko moduak eskasak dira. Partidu nagusiek, enpresa erraldoiek bezala, agintzen dute eta eratzen dute giza-bizitza.

- Gizarte eratuak, izadiko aberastasunak ahitu egiten ditu.

Kontrakulturak utopia bat eratuko du Mendebaleko gizarteak agertzen duen gizartearen eraketa horren aurka. López Ibarrondok ezaugarri horien bidez, Europan eta Estatu Batuetan gertatzen ari zen kultura bat marraztu nahi du. Garbi dagoenez, frankismo pean horien ezagutza bazen ere, zail samarra gertatu zen, diktadorea hil arte behintzat, ideia guztiak askatasunez agertzea, han eta hemen, baina, baziren zantzuak, eta horregatik, atzeratzen du ikerlari honek 1975. urte arte kontrakulturaren agerraldi teorikoaren agerpena Espainian.

Euskal Herrian antifrankismoaren estalpean, krisialdiaren agerbide batzuk lehenago agertu ziren, Espainian bezala, bestalde, eta margo nagusi horretan alde batera geratu diren joeretan.

Euskal Herrian, bestelakoak dira krisialdiaren zantzuak. Alderdi politikoak debekatuak irauten duten neurrian, zaila da, alderdi politikoetan partehartzen uztea, pasotismoa ez da zuzenean gurean gertatzen den ezaugarrietako bat.

Frankismo peko giro grisean urrun ikusten da Europa eta Estatu Batuetan gertatzen ari den giroa. Berezia da joera, berezia diren bezala erregimenak sorturiko gizartea eta politika. Horregatik modernitatearen zantzuak oihartzun bereziak izango ditu gure artean. Giro grisa da, bai, eta Frankismoak jartzen dituen hesiak ere gogorrak dira. Baina, Norbert Elias soziologoak ikusi duenez, badira gizarteetan hesi guztien gainetik agertzen diren mugimenduak. Bi dira garai hauetan aipatu beharrekoak: hazkuntza ekonomikoa, turismoaren hazkuntzarekin, eta horrek dakarren ohituren eta pentsakizunaren irekiera. Telebistaren sorrerak eta amerikarrekin egiten diren paktuek modernitatearen pentsakizunaren zabalkundea dakarte. Ez litzateke ahaztu behar Beatles taldeak sortzen duen fenomeno sozialak dakarren aldaketa. Ez dakit garaian bizitza molde bi, ofiziala eta erreala, ez ote diren zabaltzen ari urteotan. Baina, garbi dago garaian askotan erabiltzen den 
"belaunaldien arteko gatazkak" ilunpean dagoen eta bere indar guztiez azaldu ez dezakeen espresio molde baten agerpena egin duela.

Krisialdiak bere joera bereziak hartuko ditu Euskal Herrian, erregimenaren aurka politikan egiten den erasoaldiarekin, nazionalismoaren berreraiketa sortu delarik, eta, Europan anakroniko emango lukeena, Elizaren krisialdiarekin.

Europako elizan Vatikanoko II. kontzilioaren bidez, gaurkotasunerako ematen diren pausuak garbiak badira ere, eta, beraz, eliza gizartean txertatua agertzen bada ere, Espainian eliza botere politikoaren zutabe den neurrian, eliza, gizartea, eta erregimenaren arteko lotura estua dagoen neurrian, elizan gertatzen den krisialdia berez gertatzen da krisialdi politikoa.

Europan anakronikoa ez da elizak gaurkotzeko egiten duen ahalegina, estatuaren eta elizaren artean dagoen botere banaketa falta baino. Euskal Herrian elizak krisi bikoitza bizi du : batetik, gizarte osoak bizi duen sekularizazio prozesua bizi du, seminarioak hustu egiten direlarik, apaizen eta langileen arteko loturak estutzen direlarik, nazionalismoaren defentsa indartu delarik, gazte mugimenduak (HOAC) eta langileen artekoak (JOC) kristautasunaren barnean zabaltzen dituztelarik.

Paulo Iztuetak (1996: 171-176) gizartegintza deitu duen atalean nabarmenki agertzen dira gaurkotze prozesuak, aggiornamento famatuak dakartzan aldeak. Eliza pobrearen aldarrikapena, Gogor apaiz taldearen sorkuntza eta 1968. urtean egiten den Derioko Seminarioaren okupazioa nahiko adierazgarri dira gatazka eta krisialdiaren agerpen orduetan.

Sekularizazioaren adierazpiderik garbiena, baina, agian, seminaristen bokazioa galtzean aurki dezakegu. Taula estatistikoek oso ongi adierazten dute zer nolako eragina izan zuen modernizazio prozedurak honengan guztiarengan. 1963-64 ikasturtean 781 seminarista ziren Euskal Herriko seminarioetan, 1968-69, 383 eta 1974-75. urtean 91. (Iztueta 1996: 193)

Euskal Herriko elizaren krisia beste zerbaiten metafora da, mendebalde osoa da krisialdian. Hala ulertu du elizaren historia honetan jarraitu dugun Paulo Iztuetak ere :

Gizarte berriaren eraikuntzan, Elizak kontzilioaren izpirituak asko edo gutxi zurgatu duen ala ez alde batera utzita, galdetu beharko da, eredu sozialistaren eta kapitalistaren arteko kinka latz honetan, zer-nolako alternatiba berriak eskaintzen diren etorkizunari begira. Maila instituzionalean huts egin duena ez baita Eliza bakarrik, baita sozialismoa eta liberalismo demokratikoa ere. (1996:197) 
Garbi ez bada geratu zein egunetan gertatzen den sozialismoaren eta demokrazia liberalaren arteko kinka, 60. hamarkadaz edo gaurko egunez ari den, alegia, eta sozialismoa, ideia politikoa, eta liberalismo, ideia ekonomikoa, planu desberdineko ideiak konparatzen baditu ere, arrazoia du, neurri batean, krisialdia (eta Pariseko 68ko Maiatza hor dago froga gisa) orokorra da, gehienez ere elizak Euskal Herrian ageri duena beste zerbaiten sintoma da, Espainiako erregimen politikoak dituen berezitasunen sintoma, gehienez ere.

Euskal Herriko egoera berezia bada eta krisialdiaren oihartzunak beste kanpai batek joak badira, ikuspegia Artzerengan jarriz gero, bat-batean ikusiko dugu idazleak zerikusi handiagoa zuela Europako krisialdiarekin eta ez Euskal Herrian gertatzen ari den elizaren ibilbidearekin. Datu bi ditugu hori frogatzeko. Batetik, garrantzitsuena, badakigu Isturitzetik Tolosan barru (1969) liburua argitaratu aurretik Europako lurraldea zeharkatu zituela: "Hankak astindu eta aldegin zuen [...] 20 urteko "gazte kezkatsua" Suezi, Londres, Portugal, eta Salamanca aldetik ibilli zen.” (Beloki 1975)

Eta badakigu, bestetik, Paulo Iztuetak berak artistaren berezitasuna eman ziola honako hau idatzi zuenean: "J.A. Artzek, oso bere bidea eginez, poesia plastikoa lantzen du gehienbat." (1996b: 361)

Kanpoan ibili zelako, kanpotik dabilelako (Artzeren liburuak Milanen taiutu eta grabatzen ziren), Artzek bazuen arrazoirik bere bidea egiteko Europan bizi izango zen krisialdiaren aurrean. Honek guztiak gure hipotesia sendotuko luke: hau da, Artzeren poesiak badu zerikusirik Europan eta Estatu Batuetan, Mendebaldean oro har, gertatzen den krisialdiarekin; ez da dudarik ezin dela bere poesia (eta poesiak dakartzan mezuak) Euskal Herrian gertatzen den berrikuntzarekin banandu. Baina, joera berriak ekarriko ditu, ez da gutxienekoa bere abangoardia, poesia konkretuaren ezagumena, bere praxis poetikoa.

Baina, ez da forma kontua bakarrik. Artzek, egia da, poesiaren alde fonikoan eta irudian jarri du hasieran arreta:

Poesia konkretua poesia esateko edo idazteko beste era bat da. Zaila definitzen... Izen asko eman zaizkio : ikusteko poesia edo poesia bisuala, poesia konkretua, poesia fonetikoa, poesia esperimentala... (Beloki 1975)

Badaki formen berri, badaki eskolen berri, baina, gainera, forma aldaketak dakarren askatasun nahia bizitzan bizi den askatasun deiadarren paraleloa da. Herrigintza ohi da garaiko hitzik aipatuena. Poesia hau herrigintzaren beste alde bat da. Artze ez dago isolaturik. Ez dok hamairu taldeko partaide da, poesia formalak bere formaz gain egin du espresamoldeetan. 
Xabier Letek ere 1968an agerturiko poema liburuan antzeko mezuak agertzen zituen.

Zer gorrotatzen zuen (eta zer maite) jakiteko badago bere lehen poema liburuan testu esanguratsua: "Madarikatua" dei dezakegu, baina, "eten gabe ozen esateko leloa" du izenez, hau da, errosario errezuaren kontrairudia. Hortxe agertzen du Artzek nola gorrotatzen duen hipokresia, nola lan-esplotazioa, nola alkoholaren menpekotasuna, askatasuna beldurrez estaltzea, heriotzaren bakea.

"bihotzaren tokian

makinak ipintzen saiatzen haizena"

madarikatua izango da, eta madarikatuak

"bizi nahi eza

zanpaketak

zurikeriak"

Giza kontzientzia berri bat ari zen hazten eta giza kontzientzia horretan nagusiak dira kontrakulturak agerturiko bideak: nitasunaren eta gizakiaren agerbide sozialak, elkartasun berri baten bilaketa, erotismoaren formak...

Garai berria ari zen sortzen eta Rikardo Arregiren joeretatik, Leteren poemetara, Artzek bere bide propioa egin du, baina, beti ere inguruarekin lotuz bere lana.

\section{Askatasuna, lehen soinua.}

Askatasuna, zibilizazio batek dakarkigun morrontza salatuaz. Askatasuna : odola, beldurra, gogorkeria, nagusikeria ta iñungo kate ta kaiolak eten eta uxatu nahi dituana. (Lekuona: 1970)

"ama!

eten dezagun

lehen gorputzarena bezala

orain

gogoaren zilbor hestea."

(ITB, tafalla)

Eten dezagun gogoaren zilbor hestea. Egin diezaiogun aurre aurrean dugun gizarteari! Ama, giroaren ezaugarri, bizitza arruntaren agerpide, eta poetaren gogoa aurrean bere askatasun nahiak erakutsiz. 
Askatasun hori alde intimoan kokatzen du poemak : amaren iritzietatik urrundu nahi du poetak, bere bide propioa eraikiz. Baina, egoera pertsonal horretan nola ez ikusi beste zerbaiten metafora? Giro itogarriaren aurrean poetak laguntza eske, erregu gogoz eskatzen dio amari arnasa hartzeko behar duen askatasuna. Baina, ama egoera zaharraren sinbolo bada ere, ez da, ama delako, gizarte itsuaren sinbolo huts, tartean, mugan mugitzen da, baina, poetak badaki amaren alde intelektualetik urruntzen, bihotz-berotasuna gordetzen du maite duenaren aurrean; elkartasuna eta baimena bilatzen ditu oraindik poetak.

Baina, "haiek" batek aldeztuko du laster kulturak eta egoera politikoak erakusten duten alderik deshumanizatuena;

"txori ttikia nintzelarik

esan zidaten

kaiolan bizitzeko sortua nintzela

orain

arrano bihurtu naizenean

kaiola hautsita

aldegingo dudan beldurrez,

libro naizela sinestarazi nahi didate"

(ITB, irati)

Haiek gordetzen dute txori ttikia kaiolan, haiek - izenik ere ez duen izaki krudel erraldoiak- libro dela sinestarazi nahi diote arrano handiari. Izenik ez izatea bada makinaria horren lehen ezaugarria, bigarrena bere ahalmena da: gai da indarrez kaiolarazteko eta gai da askatasunik ez dagoen tokian askatasunaren irudia sortzeko (agian telebistari egiten zaion kritika? Ez dakit, beharbada, orokorragoa da hor egin nahi den kritika). Izenik ez duenak ahalmena du kaiolatzeko eta kaiola ere askatasuna dela sinestarazteko.

Gizartea eta kultura gizakia eta bere nortasuna irents ditzakeen makinaria gisa agertzen dira. Gizakiak ez du irtenbide handirik egoera horretan.

López Ibarrondok (1991: 122) idazten duenez:

Gizakiak, hala dio kontrakulturak, geroago eta zailtasun handiago du berak, bere ahalmen zientifikoen eta teknikoen bidez, sortu duen girora egokitzeko. Geroago eta galduago ikusten du bere burua, deshumanizatuagoa hiri nagusiaren erdian, komunikabide handien erdian, bizitza erosoago egiten omen dioten aparailuen artean. 
Fromm-ek lotura garbiagoa egiten du norabide faltaren eta industria erraldoiaren artean (1973: 30-33):

Gizarte bakoitzak dagokion giza-nortasuna sortzen du [...] Nolako gizakia behar ote du gure tamaina handiko industrializazio burukratizatuak?

Talde handietan lasai lan egingo duen gizakia behar du, geroago eta gehiago kontsumituko duena eta bere atsegin estandarizatuak erraz zuzendu eta igarri ditzakeenak. Aske eta libro sentitzen diren gizakiak behar ditu, baina, era berean, zuzendaritza estimatzen dutenak, eurengandik espero dena egiteko prest daudenak, oztoporik gabe makinaria sozialera egokituko direnak (...).

Industrialismo modernoak arrakasta handia lortu du gizaki hori produzitzerakoan. Gizaki "alienatua" da. Alienatua da bere ekintza eta indarrak beragandik urrundu diren neurrian; bere gainetik dira eta bere aurka; berak sorturiko baldintza ekonomikoen eta politikoen atxilotua da.

Fromm-en azalpen guztia metafora batean laburtzen da: txori kaiolatu eta libro dela uste duen arranoaren metaforan. Zein ongi egokitzen zaio ideia horri bere patuaren nagusi ez den txoriaren ideia! Artzek beste era batez ere eman du horren berri poema honetan:

"dana

gizonen zerbitzurako

ta gizona,

gizonaren zerbitzurako ez?"

(ITB, aiala)

Artzek aurrean, ez da dudarik, zapalketa politikoa du. Bere askatasunak aurrean dauka egoera hori, baina, ez du hori bakarrik bilatzen, zerbait sakonagoa bilatzen du, agian, zentsurak ere ez zuelako askatasun politikoaz hitz egiterik.

Askatasun hitz nagusi horren azpian, askatasun politikoa ere badagoela baietsi behar bada ere, nabarmenagoa da hurrengo liburuetan, irudi zehatzak aukeratu dituenean poetak, formak eta irudiak, beste arlo semantikoetatik datoz: industrializaziotik, adibidez, edo fariseismo sozialetik. Irudiak eta tipoak: pobrea, atso aberatsa, gizartean gora doan pertsona, portugaldarra, orokorregiak dira eta ekonomia eta bizitza sozialera arreta handiagoz begiratzen dute eta ez alde politikora.

López Ibarrondok, agian askatasun politikoa lortua zuen Europan buruan izanik, hauxe idazten du: 
Utopia horrek bat-batean eta gogoz, kontsumo-gizartea eta ekonomiaren eraketa ukatzen ditu, osoa den ukazioz, nolako gizarte alternatiboa bilatzen den pentsatzen hasi aurretik.

Utopiak ez du nahi asmatu etorkizunean guztia ongi izango duen gizartea; bizi duen gizartearen alternatiba orain eta hemen eraiki nahi du [...].

Utopiak gizartearen dekadentziaren bukaeraren eta gizaki berri baten jaiotzaren berri ematen du. (1991: 154-5)

Aurreko lerroetan arreta jarriz gero ohartuko gara politikaren desagerpenez. Hain zuzen ere, gizarteak eta ekonomiak toki handia dute, beste era bateko arrazoiengandik, Artzeren poesian.

Ekonomiaren kritika industriari egiten dion kritikan agertuko litzateke, batez ere. Nolanahi ere, klaseen arteko borroka agertzerik ez dagoen gizartean, aberatsen eta pobreen arteko kontrajarpenek eta nagusien eta morroien arteko banaketek osatuko dute Artzeren mundu sozialaren agerpena. Orokortasunaren alde egin duela? Bai, ziurki. Eta, agian, horrela desideologizatu egiten da gakoa; edo inguruz aldatzen da hiztegia; gizartearen barneko gatazkaren adierazpide den hiztegia, hiztegi morala bihurtzen da.

J. M. Lekuonak (1970) joera honetan kritika eta ironia era berean sortzen zirela kontuan harturik, "pikareska joera" zegoela testuetan aipatu zuen. Hala da; hiztegiak zehaztasunez galdu badu ere, ulerkortasunez irabazten du.

Txiroen eta aberatsen arteko gatazka horretan ironiak ez ezik, karikaturak ere paper handia betetzen du. Ugariak dira gai horren inguruan osaturiko poemak, beti ere beren joera sinple horrekin. Gogoangarriena, behar bada, "Itxuraldaketa 3" deiturikoa da (ITB: 51-53) non Enekotxo izatetik Exusissimus donune Ignatius izatera heltzen den gizakiaren bizitza kontatzen den, adibidean ere, azkenean, gainbehera paradoxiko eta etsigarrian bukatzeko.

Ildo honetan esanguratsuagoa da beste hau:

"nausikeriaren musua

motza

heriotza

lotsa beltza

bere legea

gezurra

makurra

lapurra."

(ITB, balmaseda) 
Karikatura heltzen da, nola ez? liburuak mantenduko duen eliza ofizialaren aurkako joeragatik, karitateari egiten zaion kritika, azken batean, beste zerbaiten ordezko baita karitatea, gizartean egon beharko lukeen justiziaren ordezko, hain zuzen ere:

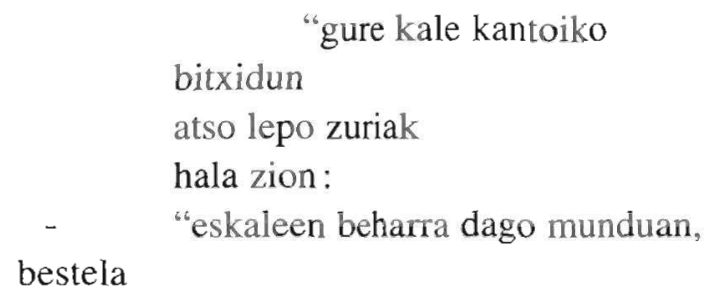

norengan egingo genduke karitatea?"

(ITB, barakaldo)

Pertsonaia hauekin ez du idazleak ezer jakin nahi, eta horiengandik urruntzen da, zeruan bertan ere.

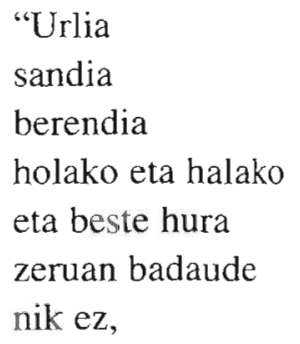

otoi!

ez dut zerura joan nahi." (SGG: 32)

Karikatura eta pertsonaien gainetik edo azpitik, industriaren aurka hiru arazo aurkeztu ditu Artzek:

Lanak deshumanizatu egiten du, batez ere, larregiko lanak;

- Industriak izadia zapuztu du, eta horretan Oria ibaia litzateke metaforarik ederrena, baina, ez bakarra;

- Gizarteak kontsumismo giroan sartu du gizakia.

Denaren gainetik jarri den lana dela-eta, poema hunkigarriak idatzi ditu Artzek. Batez ere, Isturitzetik Tolosan Barru liburuan, Urdiain orrialdean lana hitzarekin poema bisuala eraiki du. Hitz horren bidez fabrika baten antza duen irudia osatu eta tartean, han agertzen da galduta "gizona". Poema berean lana, makinarekin lotzen da, makinaren irudia sortu arte, eta honela galdetzen du poetak: 
"nork lotu zaitu

nork lotu zaitu etorkizun gabeko gurdi horreri ?"

Mikatzagoa da, ezbairik gabe, poemaren bukaera non idazleak adierazten duen giro erraldoian galdurik dagoen gizakiaren harridura:

"Gizona

jana

lana lanagatik jana

makina janagatik makina

nun da GIZONA?

lepazamarretik heldu genion gizatasunari

eta mundura, nola hegoak

zabaldu genituen leihoak." (LGA : 55)

Kontrakulturaren alderik sakonekin bat dator honetan, bada, poeta: giro erraldoiaren aurka gizakiaren agerpena egin behar du poesiak.

Lanaren eraginez bada beste poema bat haren ondorio gogorrak adierazi dituena:

"nere ama hil zait

lanak itota.

lanaren amoreagatik

hil zait

zertarako dan bizitza

jakitera iritxi gabe" (ITB, egilaz).

Aipamen berezia behar du testu horrek, ez agerian utzi duen kontrajarpen argiagatik, lanak ez du bizitza zer den ikusten uzten, baizik eta baten baino gehiagotan argitaratu duelako poetak testu hori: Isturitzetik Tolosan barru liburuan (egilaz orrialdean ikusi dugunez) eta Eta sasi guztien gainetik poemategian (SGG, 52), bigarren aldaki honetan beste ortografia eta metrika aldaketen artean, "zertarako den bizitza" bitan errepikatzen duelarik bere esanahia indartuz.

Kontrakulturaren teorikoek adierazi dutenez, kultura mugimendu hori sortzen da, hain zuzen ere, hazkuntza ekonomiko handia dagoenean, eta, beraz, atsedenaldirako astia zabaltzen denean gizartean:

Bizi dugun kultura-aldaketa osoaren fenomeno erabakigarria urritasun egoeragatik aberastasun egoerara egin den pausua da. Orain mende bat munduko herrialde guztietako populu aktiboaren \% 70k lan egin behar zuen denontzako elikadura sortzeko. 
Gaur egun, Ingalaterran eta Estatu Batuetan nahikoa da populu aktiboaren \% 5aren lana denentzako elikadura ziurtatzeko [... . Gizakia lan mekanikotik libro geratuko da eta gogo lanari, arteari, sorkuntzari lotuko zaie; ikastera, ikertzera, jateari, hitz egiteari, paseatzeari, begiratzeari, maitasuna egiteari, asmatzeari lotuko zaie. Egiten dena atseginez egingo da eta ez dirua irabaztearren edo etorkizuna ziurtatzearren. (Racionero 1977: 25)

Horrela ikusten du Artzek ere gizaki berriaren egoera, lanetik kanpo, egoera zoriontsu batean.

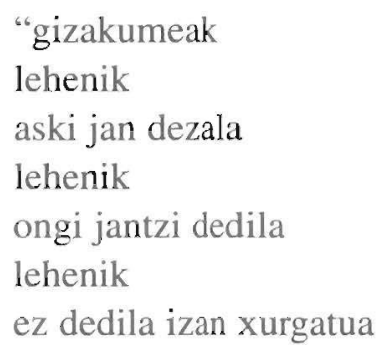

eta orduan

txorien kantuak
entzungo ditu

behe-maitasuna zer dan

ikasiko du"

(ITB, orreaga)

Atsedenerako, bizitzarako, gozamenerako astia lortzea izango litzateke kontrakulturak eskaintzen duena. Bizitzeko filosofia, azkenean.

Maffi ikerlariak Estatu Batuetako egoeraz honela dio: "Kontrakulturak hemen eta orain errealitate eroari alternatiba eraiki nahi dio, tragedia amerikarrean bakea eta atsedena aurkitu." (1977: 123)

Artean, baina industriak hiriak aldatu ditu:

"laister zingurrientzako ere

ez dugu utziko lurrik;

hil ala bizi

ormigoi ta plaztiku tartean

eratu beharko dute. 
sugeak
txirristagatik

ez atzera ez aurrera,

datorkien heriotzari so

asfalto gainean

txirtxillatuko

ditugu." (ITB, gaztehiz)

Agian hemen kontraesana ikusi genezake. Kontrakultura eta atseden astia sortzen badira industriak sortu duen ekonomiari esker da izan. Ondorioak, baina, ez dira hain garbiak. Industriak berarekin baitakar izadiaren suntsipena. Kontrakulturaren ezaugarrietako bat da izan izadira itzultzea eta sorrera garaiko garbitasuna bilatzea, geroago ikusiko dugunez. Horregatik industriak, eta industrializazioak, kondenatzen dira kutsadura, izadiaren agorpena euren lana izan delako. Alde honetatik Oria ibaia, Ez dok hamairu beste taldekide batek, Benito Lertxundik ere gai gisa erabiliko duena, galtzear dagoen izadiaren metafora bihurtu da:

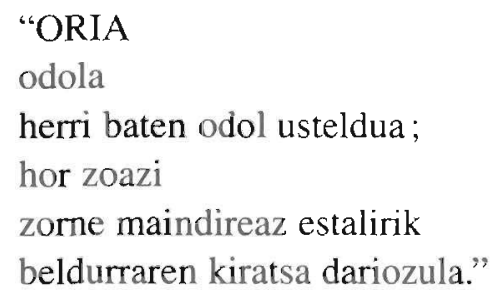

(ITB, ondarru)

Oria ibaia Artzeren poemetan ez da soilik izadi erabili eta lohitua, herri osoak sufritzen duen menpekotasunaren sinbolo ere bada neurri handi batean ibaia, poema bukatzen duen metafora lerraketak agertzen duenez:

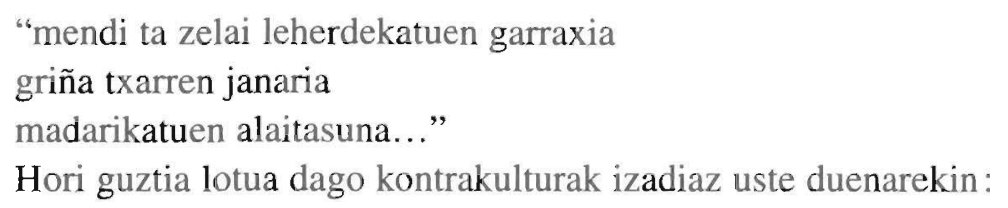

Gugan arrunta denaren aurka, kontrakulturak ez du onartzen izadia arimarik gabea denik eta gizakiarengandik at dagoenik. Tradizio erromantikoa onartuz, bat-bateko lotura dagoela gizaki eta izadiaren artean, sare organiko bakarra osatzen dutela onartzen dugu [...]. Horrela, izadi-munduaren parte garela onartu behar dugu eta bera menperatzeko ahalegina uxatu. Horregatik, eta izadiarekiko lotura hautsita dagoelako, gizakiak izadiarekiko lotura mistikora itzuli behar du. (López Ibarrondo 1991: 243) 
Horregatik, hain zuzen ere, Oria ibaia ez da industriaren salaketa bakarrik, inguruan bizi den herriaren sare eta adierazpide ere bada neurri handi batean.

Gizarte teknologikoaren ondoriorik nagusiena, baina, pertsonen barnean kokatzen da eta kontsumismoa deitzen da; naturaltasuna uxatzeko forma da. Gizarteak kontsumoa, behar ez dena erostera eta erabiltzera bultzatu du gizakia. Poetak, berriro, alienatzen gaituen, gure barrenetik ateratzen gaituen errealitatea uxatu egingo du. Lehen-lehenik kontsumismoaren sinboloak hankaz gora jarriz. Deigarria da koka kola markarekin egindako poema:

"K K

o

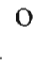

k l

a a"

(LGA, 26) edo, ildo bereko: "KOKA KOLA-ren edestia" (LGA, 27), non kontsonante larriak ( $\mathrm{K} \mathrm{K}$, alegia) irakurri behar baitira lehen-lehenik.

Kontsumoaren aurkako joera indartzen du poetak deshumanizaziorako bidea delako. Behar ez duguna hartuz, berebiziko kalteak sortzen dira, bai izadia erasotzen delako, eta baita ere pertsonaren joera ahultzen delako. Artzek, beste kasu batzuetan ikusten ez dena, arreta handia jarri du haurrengan, eta, urrundik begiratuta ideia bitxia eta sinplea bada ere, errepikatu egingo du nola sortzen den heziketa okerra kontsumismoaren bidez. Moda berriak erroen galera dakar, eta karikatura eta parodia indarrez egin ditu kalte berri hori salatzeko orduan: "Galipotakumeak" deituko ditu, hain zuzen ere, kontsumoaren eta industriaren artean dagoen lotura (galipota) azpimarratuz. Galipotakumeak, gainera, "Born in Europa" dira, baina, "Made in USA" (OL, 54):

"rocka-cola zainetan

plastikozko aurpegi zurbila zuen

-grisak begiak,

grisa autoa,

gris metalikoa-

metalezko mutikoa

mutiko automatikoa." 
Kritika honetan gogor agertzen da Artze, batez ere, azken liburuan Ortzia lorez, Lurra izarrez poemategian non modernitatean sortu duen mundu arinaren kritika egiten baitu, eta 68ko giro hark sorturiko gehiegikerien kritika zorrotza egiten den.

Askatasun politikoa, nola liteke bestela ?, egon badago lehen garaiko liburuetan. Isturitzetik liburuan alegoriak, joera abstraktoak agintzen du:

"morroin etik

tasun

tasun

gazte era."

(ITB, kalagorri)

doan bidean. Zentsuragatik giro politikoa ezin denean garbi eta zehatz aipatu, beste era bateko joerak hartu behar dira. Mikel Zarateren nobelagintzan, adibidez, horren hainbat erabilpen aurki ditzakegu : anagramak, mitoen aipamenak, zeharkako metaforak... ezin adierazi dena, adierazteko asmoz. Horrelako zenbait prozedura darabiltza Artzek ere: lan munduaren aipamena, politikan gertatzen dena metaforizatzeko, koloreen aipamen topikoa, poema txikitxo honetan legez:

"ene! gure herriko

baserrien zu ia

teilatuen gorria

b e l a r d i e t a n"

Borrokarako deia - zein borroka den aipatzen ez delarik- garbiagoa da Laino guztien azpitik lanean. Izenburuak berak ere "lainoen azpian" horrek, hau da, mundu honetan gertatzen denak, nahiko garbi adierazten du mundu honetako elementuekin jolastu nahi dela.

Askatasunerako deia garbia da zenbait poematan:

"askatuko zaituen

zai bazaude

zaude lasai

zaude ziur

askatuko zaituela

kateak itsusiak baitira hilotzen gorputzean." 
Heriotza osteko askatasuna ez loitzeko, ironia kolpe bortitzez idazleak garbi utzi duenez, borroka hori orain eta hemen gertatu behar da.

"ez dezagun borroka

gerorako utz.

ez dezagun utz

gure ondorengoek egingo dutelakoan

gure borroka

denbora eta lur honetako da,

Geuk egin beharrekoa.

geuk ez ezik

beste inork egin ez lezakeena." (LGA, 48)

Normala denez, ez da definitzen zer den borroka, edo ideologikoki nola gauzatzen den: ezin delako, batetik, eta ziurrenik poesian ezinezkoa delako hain zehatza izatea.

Txileko Estatuko kolpeak, ordea, bideak irekiko dizkio pentsakizun honi, eta Artzeren poesia moldeari.

\section{Irrazionalismoa}

"Kontrakultura erromantizismoaren kumea da" esan dezakegu zuzen, Melville-rekin batera (1976: 104). Maraise-k, kontrakulturako filosofo batek esan zuenez: "egia ez dago soilik arrazoian, irudimenean ere badago, eta batzuetan indartsuagoa da".

Artzek bere poetika batean azaldu du zein handia den berarentzat egiara heltzea eta egia, transzendentziara heltzeko bidea beti barne prozesu baten bidez gertatzen da. Neoplatonikoek egin zuten bezala, Artzek ere mundu bi ikusten ditu: azalean eta egunean-egunean ikusten dugun, eta sakona, benetakoa, bigarren maila batean aurkitzen dena. Ikusezina dena ikusaraztea liteke poetaren lana Artzeren ustez:

"Ikustezina ikusteko dago batez ere

olerkaria gizakumeen artean:

ikustezina ikusi eta

ikustarazten laguntzeko ingurukoei.

Ikustezina ikustera etorri da,

ikustezina ikustera doa

olerkaria,

eta ikustezina ikusiz,

esanezina esatera

olerkitan." (1991: 17) 
Poema honek planteatzen duena presente zegoen Lauaxeta eta Lizardiren poetikan, azken batean, neoplatonismoa beste errealitate batera igarotzeko bidea baita. Atea berdina da, helburua ere bai: Artzek ere egia adierazi nahi du-eta.

Helburua jakinduria iraunkorra bilatzea litzateke : pertsona bakoitzaren bihotzean aurkitzen den benetako garbitasuna. "Sophia perennis" hori da Artzek aurkitu nahi duena, era berean, betiko eta naturala dena:

"Jakinduri iraunkorra

lehen zena eta gero datekeena;

mundua hastean bertan zen,

mundua bukatzean bertan datekeena $[\ldots]$

den guztiaren, den denaren

Abiaburua, Helbidea eta Helburua."

(1991:19)

Bada poema bat zeinek adierazten baitu barne-ikuskizun horren beharra. Besteei dagokie, hain zuzen ere, arrazoiarekin bizi direnei eta bere txikitasunean, esanaren sendotasunean, ironian garbi uzten du barne munduak irrazionalismoak- agintzen duela:

"urrikalgarriak benetan

jende haik

begi hertsiekin ere

ez zuten dena ikusten."

(SGG, 26)

Izpiritu huts horren bila abiatzen da Artze neoplatonikoa, hor du bere poesiak helburu nagusia. Lizardiren eta Lauaxetaren neoplatonismoaren eta sinbolismoaren zantzuak entzuten badira hemen, desberdintasunik ere badago. Diferentea da aburua eta desberdina bidea.

Lauaxetak eta Lizardik gizarte jakin bat zuten aurrean, Artzek beste bat, nahiz eta zenbait puntutan berdin antzera jokatu. Kontrakulturak aurre egiten dio gizarte teknifikatuari.

Arrazoiak agintzen du mundu horretan, ikasketa zientifikoan jarraipen teknologikoan eta errealitatearen hausnarketan. López Ibarrondok honela adierazten du kontrakulturak aurrean duen mundua: 
Arrazoiaren monopolioak inguruko errealitatetik urruntzen du gizakia, unibertso balioa hausten dio, munduaren eta bere buruaren ikuskizun bikoiztua damaio, besteengandik apartatu eta bakartasunean uzten du, eta, bukaeran, deshumanizatu egiten du." (1991: 129)

Kontrakulturak aurre egin dio arrazoiaren munduari, eta irudimenaren mundua bilatzen du Parisen ("Irudimena boterea"), San Franciscon eta Pragan. Arrazoiaren aurrean sentiberatasuna eta elkartasuna aldarrikatzen dituzte garaiko gazteek. Irrazionaltasuna - gauaren erreinua- agertzeko modu asko ziren: transzendentzia nahia zen lehena, drogaren erabilpena, ekialdeko eriijioen indarra (budismoa, zen filosofia), erotismoa (mende hasieran bazen jakituriarako bide ezkutua). Alde batera utziko ditugu orain, gero astiro aztertzeko asmoz, erotismoa eta ekialdeko erlijioen agerpena Artzeren poesian. Droga munduaz ohar bi egin behar ditugu, baina, hippy-en munduarekin hain loturik agertzen den erabilpenak ez du Artzerengan eragin handirik. Artzeren lanean, baina, garai bi desberdindu behar dira: lehena lau liburuek batasun kontzeptuala osatzen dute (1969-1975) eta bigarrena Ortzia lorez, lurra izarrez (1982) ingurukoa litzateke, nahiz onartu behar den liburua argitaratu aurretik hasi zela gorpuzten joera, ziurrenik "Gizon handi bat da mundua eta mundu txiki bat gizona" ikuskizuna eratzen duen garai aldera. 1982. urtean, adibidez, elkarrizketa luze batean honela mintzo da Artze:

Garai batean gauzen koloreak eta itxurak besterik ez nian ikusten; orain, berriz, gauzen barru-barruko muina ikusten hasi nauk [...]. Inguruak agintzen zian lehen gehienbat ni baitan: ingurua huen indar eraginkorra. Alderantziz dela orain, esango niake, hau duk kanpotik barrura ordez, barrutik kanpora dihardudala. (Mollarri, 1982)

Bigarren garai honetan drogen salaketa gogorra dago Artzerenean:

"ba dirudi hemen dugula, heldu garela

erlijioa herrien opioa ziotenek

herriari opa zioten paradisura.

Heldu garenik, ordea, ez diote;

Isiltzen dute, zergatik ote?,

"opioa dela gaur herrien erlijioa"."

(OL, 52)

Aurrekoetan ere ez zegoen sikodeliaren aipamen argirik. Agian, eta agian diot, lehen hiru liburuetan - nabarmenago bi berrietan- sorginkeria izango litzateke irrazionalismoa eta sikoterapiaa lotzeko modu bakarra. 
Garbi dago beste erabateko bidea erabili duela Artzek, beste espresio moldea dela berea. Irrazionalismoaren agerbideak, zuzenean, bi lirateke: abangoardiaren erabilpena eta aitzinakoen aipamena.

Abangoardia espresamoldeetan darabil Artzek. Kintanak 1975. urtean ikusi zuenez: "euskal onomatopeien balio esthetikoa" da Artzeren balio poetikoetarik bat. Poetak ere futuristen eta dadaisten iturria aipatzen du bere lana egiterakoan. Hitzaren alde fonikoari - eta ia fonikoari bakarrik- eutsiz zentzuaren mugetan jartzen da Artze. Hasierako liburuetan, kanpo aldeak hain eragin nabarmena zuenean, foko fonikoak berebiziko garrantzia du. Bai "Zetaren maitasun kontuan" (ITB, barkoxe)

"zir-zir
zapa-zapa
zapla-zapla
zanga-zanga
zar-zar
zizt
zara-zara
zizar
zizare"

bai ikimiliklak, soinuen lotura hutsak, sortzen dituenean, eta horrelako sail luzea osatzen du Laino guztien azpitik liburuan (30-39).

Forma guztion helburuaren azalpena Maffirengan aurki dezakegu:

Underground-ak publikoaren partehartzea ezinbestekoa zen forma artistikoak sortu zituen, honela gizakia ikusle soila izatearen egoera lasai eta pasibotik ateratzen zuten, ikuslea: erantzunik eza, partehartzerik eza; norberen agerpenik ez; sorkuntzarik ez. (1977: 38)

Artzek jotzen duen musika-tresnak ere berak bizi duen batasun-gogoaren sinbolo ere bada. Txalaparta musika-tresna zaharra dugu, tradizionala, baina, musika baino gehiago, zentzu logikorik gabeko soinua egiten du, abangoardiatik hurbil. Isturitzen ditugu erroak, erro tradizionalak, baina, Tolosan bizi gara. 
Hauxe liteke erroetara heltzeko bigarren bidea. Oteizaren Quosque tandemen eragina nabaria dela esango nuke, azken batean Oteizak azaldu baitu historiaurrean kokatzen dela euskal sena, sentsibilitatea. Artzek ere aitzinakoengan jartzen du bere euskaldun sena : ez da errorik gabea, historian egina ere bada. Esanguratsua da, alde batetik nola urruntzen den kristautasunetik Artze, eta bilatzen duen antzinakotasuna:

"gizasemea = kristaua

euskalduna $=$ fededuna

kontuz!!

bestela

gure asaba zaharrak

haserretuko dira"

(ITB, hiriberri)

Euskal historia zahar baten bila abiatzen da Isturitzetik Tolosan barru liburuaren azalerako jarritako irudi-puzzlean Euskal artea, euskal literatura, euskal historia gorpuzten dira hor bere konplexutasunean.

Euskal historiak agintzen du ere Laino guztien azpitik historiako zenbait gertakizunen datekin hasten den poeman:

“ $1200,1332,1379,1512,1609,1789,1794,1839,1879$,

$1931,1937,1966,1971, \ldots$

arrano beltzarekin joan ziren

joan

Jaengo Navas de Tolosara

Nafarrak

eta kateekin itzuli ziren etxera."

(LGA, 39)

Egia da estetika hutsetik banatzen dela poema hau. Oteizaren teoriaz landa, testuak nazionalismoaren defentsa egin nahi duela, "euskal derroten" zerrenda eginaz eta kanpokoen arriskua azpimarratuz. Baina, hala ere, historiak duen garrantzia agertzen du testuak.

Aurre historiak soka luzea du, eta euskaran mamitu da lotu gabe etorri den uraren higidura. Berak gordetzen du aztarna zaharra, zentzurik gabeko soinuan gorpuzten dena: 
"maite zaitut

euskera

gurea zeralako,

zugan sortu naizelako,

milla ta milla urtetako

herri baten

lana

mina

maitasuna

zoriona

zugan osatuak daudelako;

zure bitartez

haien berri jakin dudalako"

(ITB, bozate)

Euskara da ura :

"Iturri zaharretik

edaten dut,

ur berria edaten,

beti berri den ura,

betiko iturri zaharretik."

$$
\text { (OL, 107) }
$$

\section{Erotismoa, Elkartasuna}

Gizartearekiko urruntasuna adierazten duen "etengabe ozen esateko leloa" poeman, gogoratuko dugunez madarikatuen zerrenda hartan, bada errukarria, eta ez madarikatua den bat:

"errukagarria Jainkoa begira daukazulakoz

zure gorputzaren edertasunaz

ahalgetzen zerana."

(ITB, oñati)

Gorputzaz ez da lotsatu behar. Gorputza, erotismoa lehen aldera dator. Komunikazio bidea da, elkar ulertzeko, elkar maitatzeko ezinbesteko modua. 
Mendebaldeko kulturan eta kristautasunaren eraginez, gorputzaren "ahazmena" gertatu da, arima eta gorputzaren arteko dualismo gogorrean, kontrakulturak erlazio berriak asmatuko ditu sendiaren barruan, talde erlazio sortuz ("komunak") eta bikote erlazioetan, sexu askatasunaren bidetik. Helburua norberen ezagutza lortzea litzateke, jakinduriaren aldetiko proposamen berria.

Gizarte arrazionalistak ez du gorputzaren alde ezer egin, gehienez ere ukatu egin du haren ahalbidea.

Gure gorputza entzuteko edo gorputzaren bidez adierazteko ukazioaren oinarrian gorputzak ezer ez dakiela adierazten duen ideia dago. Eta zerbait baleki, gaizki jakingo luke. Gorputza grinen eremua da eta ezin dugu bere autonomia onartu; gutxiago gure pausuen gidaria daitekeela. Gure mugimendu guztiak "burua" ren (gogoaren) menpe jartzen ditugu, horixe baita "zentzuz" aritzeko modu bakarra. (López Ibarrondo 1991: 127)

Gorputza onartzea norberaren ezagutza bidean lehen pausua da.

"Gorputzaren ezagutza barne askatasunerako lehen prozesua da. Ezagutu eta hartu behar den mundu bat da, pertsonaren askatasun bidean." (López Ibarrondo 1991: 159)

Ideia, dirudienez, Maffi-ren La cultura underground liburuan era estuago batean agertzen da:

Sexua zinemara eta teatrora, narratibara eta egunkarietara eraman zuen... bizitza sortzailearen atal izatearen funtziora itzuliz eta bere ahalbideen osotasunean sinestuz: sexua joko gisa eta bere osotasunaren agerpenean nitasunaren adierazpen pozgarri gisa, biluztasuna eta besteengana joatea. (1977: 38)

Ildo beretik agertzen dira hainbat ideologia: feminismoa, homosexualitatearen onarpena, biluztasuna, ekialdeko tekniken hedapena, gorputz-adierazpenen tekniken ezagutza...

Irakurri dugun idazle horrek, baina, banaketa garbia egin du. Bere aburuz, biluztasunaren aldeko jarrera eta askatasun sexualaren aldekoa ekintzen eremuan kokatzen dira, baina:

"Desioaren, pozaren eta plazerraren aldarrikapena sarriago aurkitzen da, hitzetan baino sarriago, poesian (Walt Whitman-en itzulera)." (López Ibarrondo 1991: 167)

Hementtxe kokatzen da, eremu honetan Artzeren poesia ere : plazarraren aldeko joaerak bereak.

Aspaldiko kritika batean ohartu zen joeraz Edorta Kortadi: poesia honetan erabiltzen diren gaiez mintzatu zenean: 
Ori poemak, gure historiko izatearen zeruan hegan dabiltzanak eta zenbait gai berdin erabilitzen dutenak:

a) Biziari eta lurreko gauzei amodioa.

b) Kreaturaz gozatzea eta zerura joan nahi eza.

d) Kristautasun historikoak zapaldu dituen gorputz erotikoaren alderdiak altza nahia. (Kortadi 1974).

Emakumea, esango digu Artzek, ez da gizarteak zapaltzen duen gizakia ("ama hil zait lanak itota"), ez da "paper tradizionala" betetzen duena, gizakia da.

"gu

la $\mathrm{n}$

lagun" (SGG, 56)

Elkartasunaren lema nagusira heltzeko lehenik, maitasunetik igaro behar da, emakumearen izaeraren alde jarrita, gizonezko zein emakumezko pareko direla adieraziz.

Mezu horrekin idatzi du Artzek maitasun poemarik hunkigarrienetakoa:

"hegoak ebaki banizkion

nerea izanen zen

ez zuen aldeginen.

bainan,

honela

ez zen gehiago txoria izanen

eta nik...

txoria nuen maite."

(ITB, santimamine) 
Maitasunaren gaiak noiz edo noiz joera ironikoa hartu badu ere:

$$
\text { "senarrak emazteari }
$$

bere haurren ama izatea

$$
\begin{gathered}
\text { bakarrik } \\
\text { eskatzen dionean } \\
\text { probetxu ona duelako da auzoan } \\
\text { ba ote luke hainbeste } \\
\text { emazteak ere beste nunbait balu?" }
\end{gathered}
$$

Normalean, tonuak pertsonaien arteko sentimenduen finezia lantzen du, elkartuz lortzen den zorabioa gozatuz, bik bat egiteko orduan sortzen den plazerra argituz.

$$
\begin{gathered}
\text { "ni hustu } \\
\text { eta zu puztu } \\
\text { zerbait zu baitan } \\
\text { da piztu" }
\end{gathered}
$$

Maitasunean aurkitzen du Artzek mundua ezagutzeko giltza. Horrela batzen dira emakumea eta oroa, batak besterako zubi delarik.

$$
\begin{aligned}
& \text { "zugan dagoke } \\
& \text { zugan datza } \\
& \text { egia osoa } \\
& \text { zugan eta oroan } \\
& \text { oroan eta zugan } \\
& \text { oroan." }
\end{aligned}
$$


Noizbait tonu metaforikoa eta poetikoa erabiliko du, poema liburuan behin eta berriro errepikatzen den honen kasuan bezala.

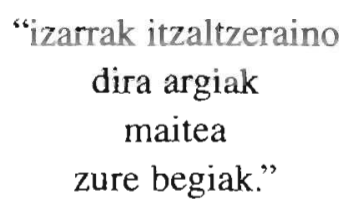

(SGG, 27)

Baina, besteetan gordin ari da, Juan Mari Lekuonak ikusi zuen pikareskaren bidetik, bertsolaritzako ironiaren moldeetatik hurbil.

\author{
"hauzoko gelan \\ eta ohean \\ neska mutil gazteak guri guri \\ maitasun kontua ziren ari."
}

(LGA, 44)

Tonuak desberdinak badira ere, garbi dago maitasunean aurkitzen duela poetak "jakinduria iraunkorra", bere ohiko moldeak "desikasteko" metodoa, bere benetako sustraia erakusten duen moldea.

"neure maiteari ematen natzaionean

barruz lehertu arteraino

eman nahi nintzaioke

ez izateraino gorputzen izan

gainezkatzeraino naizen guztia ixuri..."

Maitasun kontuak, oro har:

$$
\begin{aligned}
& \text { "gizakumearen kantuak } \\
& \text { badu besterik } \\
& \text { xoriarenak ez duenik." }
\end{aligned}
$$

Maitasuna, "bestearekiko" batzeko bidea da. Beste hori hasieran emakumezkoa da, baina, zirkulua zabalduz doa, eta maitasuna elkartasunerantza- 
ko bidean doa, nahiz eta kontrakulturaren garaietatik urrun idatzitako liburuan, Ortzia lorez-en alegia, sexu-askatasunaren gehiegikeriaz kexu den poeta :

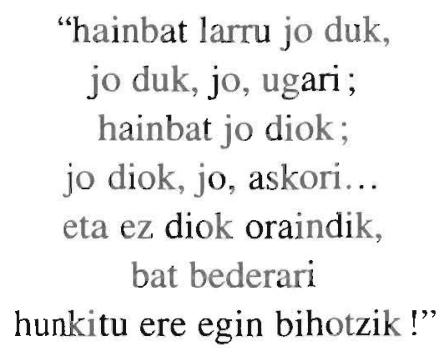

Artean, baina, hasieratik Artzek ez du nahi zapalketarik, ez du nahi deshumanizaziorik, alienaziorik: gizakiaren barnerantz jotzen du gure lanez lagunak sortuz.

Maitasuna elkartasunerako bide da:

\author{
"beste bat \\ beste bat bakarrik \\ ezagutu ahal ukaiteko \\ zoria edo \\ ausardia bagenu \\ zer kate gogorra gendukean etengo \\ zenbat eta zenbat \\ ez ginakean gehiago lehengoak izango \\ zenbaiten zorion mugak \\ liratekean zabalduko."
}

(LGA, 21)

Gizarte ordenatuan ondokoa aurkaria bada, konpetitzailea, kontrakulturan ondokoa beste zu pertsonala da, onartzen den gizakia, bere alde egiten da, "laguna" (eta hitzaren zentzu biak hartu behar dira kontuan) bilatzeko asmotan. Norgehiagokaren ordez, elkartasuna; hiri modernoak jartzen dituen oztopoen ordez, ezagutza pertsonala.

Joera honetan Artzek modu bitan agertzen du bere bestearekiko jarrera. Batetik alde literarioa dugu; bestetik, ideologikoa. 
Alde literarioan eta abangoardiarekin jarraituz, Artzek irakurlearen. partehartzea eskatzen du. Ez horrenbeste lehen liburuan, baina, Laino guztien azpitiken agertzen da irakurlearen partehartzearen joera : alderantziz idatzitako hizkiek irakurleek ispilua har dezatela eskatzen dute eta ispiluan zuzen. irakur dezatela; letren ordez, zenbakiz idatziko ditu poemak Artzek eta honetan ere beharrezkoa da hartzailearen lana, letra bakoitzaren azpian ezkutatzen den letra ezagutu eta klabe gisa irakurri beharko du poema; zenbaitetan poemak hutsik ematen ditu Artzek irakurleek bete dezaten, (SGG, 53) edo zuzenean eskatzen dio bere lana:

"Liburu honi falta zaion zatia

beha ezazu,

hor, zure etxean nonbait gorderik dago.

zure eta neurearen arteko bidea

erdiraino ibiltzen saiatu naiz;

ezin ninteke aurrerago joan."

(SGG, 1)

Idazlearen eta irakurlearen arteko konplizidaderik nagusiena eskaini. du poetak Bide bazterrean hi ta ni kantari liburuan. Irakurleak liburuko hizkiak marraztu behar ditu, hitzak ager daitezen.

Alde ideologikoan, Artzek harreman handia izango du irakurlearekin: zuka forma askotan agertu da poemetan, orrialdearen beste aldean dagoeneko bila joateko ahaleginetan balitz bezala.

Eremu honetan esparru bi bereiztu behar ditugu. Artzek ez ditu neutralak onartuko:

"inpernurik bada

etor dedila

bainan

ez dut

ez dut nahi

ez dut nahi iñolaz

ez dut nahi iñolaz behintzat

linboan

sartu."

(ITB, urepela) 
Gogor aritzen delarik, historian ezer egin gabe geratu direnekin. Isturitzetiken arratoi batek jaten duen Joxeren istorioa kontatu du. Bakeagatik ez du Joxek ezer egin eta arratoiak desagerraraziko du Joxe. Sasi guztien gainetik-en joera abstraktua bezain gogorra da:

"galdu dutenekin elkartuko naiz

$$
\begin{aligned}
& \text { bainan, ez } \\
& \text { sekulan ez }
\end{aligned}
$$

jokatu ez duenarekin."

(SGG, 51)

Baina, behin, neutralak eragotzi ondoren, elkartasuna bilatuko du poetak, bere ahotsa besteen ahotsarekin bat eginez; bere patua besteen patuarekin bat eginda dago; sare nagusi eta misteriotsu batek biltzen ditu poeta eta bere garaikideak elkartasunaren harian. Horrela, poetaren askatasuna besteen askatasunarekin biltzen da, eta ez dago askatasunik denak aske ez badira:

"zure askatasunagatik

borrokatzen banaiz

kantatzen badut,

ez dut, urrikia dizudalako

kantatzen. [...]

zure askatasunean

zure zorionean ez ezik

ez baitut neurea

beste inun ikusten."

(SGG, 60)

Baina, lotura ez da soilik ideologikoa; afektiboa ere bada. Poesia pertsonak lotzeko komunikazioa da, elkartasunerako bidea, sufrikarioa den historian. Ahotsen arteko lotura sentimenduen arteko ere bada. "Nere hitzak berenak bihurtu artio" irakurri behar ditugula baieztatzen du poetak, bere kanta besteena bihurtu arte arituko da lanean.

Irakurlea bakarrik dagoenean, Artzeren kantua izango da lagungarri. 
Eta sasi guztien gainetik liburuaren atzeko azalak ongi adierazten du zein den poetaren helburua, nola bete nahi duen bere eginkizuna:

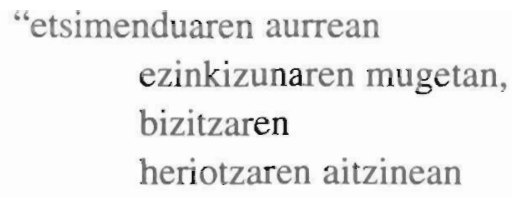

Horixe da poetak lortu dezakeena: lagungarria izan bakarrik daudenei. Baina, behin elkartasun horretara helduz, poetaren izaerak lau errealitate desberdin batuko ditu : bere nortasuna, maitasunean aurkitzen den bestea, elkartasunean batzen den gizakia eta harago dagoen izadia. Kontrakulturako aztertzaileek idatzi zuten: "Bizitzaren lehen hazitik neba-arrebak gara, sabel beretik datoz gure gorputzak. Hemen lurrarekin bat gara, eta gure Ama bezala ezagutzen dugu." (Melville 1976: 171)

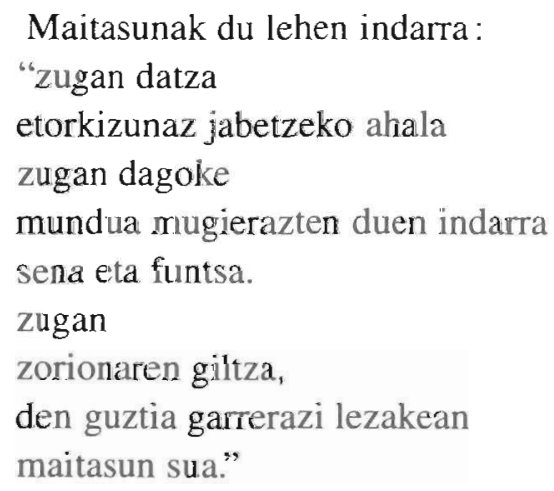

Poema hau, Eta sasi guztien gainetik liburuko azalean beste guztia beltzez den artean, esanahia azpimarratuz, zuriz ematen da.

Maitasuna elkartasunerako bidea da eta elkartasunak inguruarekin, edo izadiarekin bildu gaitu: norbera ezagutzeko borrokan, norberak norberaren barnean inor den jakiteko egiten duen bidean aurkitzen da laguna, eta lagunak bat-batean darama izadira. 


\author{
"borroka hortan \\ ilhuna argiz adierazten denean \\ gizakumeak gizakumearekin topo egiten du \\ eta borrokari lotzean \\ erroz dira elkartzen
}

borrokari lotzean

den eta dabilen guztian kokatuz

eta Inguruarekin bat izanaz

Inguruaren etengabeko higiduran."

(SGG)

\title{
5. Izadia
}

Kontrakulturak gizartearen aldaketa nahi zuen, eta gure aldetik aztertzeko dugun azken gaia izadia da. Arazo honetan ere gizarteak eratu duenaren aurka agertzen da kontrakultura. Industria izadiaz baliatzen bada beste ezertan pentsatu gabe etekin ekonomikoak ateratzeko, kontrakulturak beste helburu batzuekin egingo du lan. Pentsakizun horrentzat izadiaren eta gizadiaren arteko zubia etenezina da. Dena elkarturik dago kosmos nagusiaren pean.

Gugan arrunta denaren aurka, kontrakulturak ez du onartzen izadia armarik gabea denik eta gizakiarengandik at dagoenik. Tradizio erromantikoa onartuz, bat-bateko lotura dagoela gizaki eta izadiaren artean, sare organiko bakarra osatzen dutela onartzen dute [...]. Horrela, izadi-munduaren parte garela onartu behar dugu eta bera menperatzeko ahalegina uxatu. Horregatik, eta izadiarekiko lotura hautsita dagoelako, gizakiak izadiarekiko lotura mistikora itzuli behar du. (López Ibarrondo 1991: 243)

Ikuspegi honetatik, kontrakulturak alternatiba naturala sortuko du, eta hainbat ekintza desberdin, hainbat arlo indartuko dira: ekologia litzateke alderik nagusiena, baina, medikuntza naturalaren hedapena, osasun makrobiotikoaren ezagutza, lurlangintza biologikoa, arkitektura ekologikoa, herri kulturen bultzapena garaian gertatzen diren fenomenoak dira.

Industriaren aurkako joera horrek berebiziko indarra hartuko du Euskal Herrian indar nuklearraren aurka egiten diren manifestazio guztietan.

Artzeren poesiara itzultzen badugu begirada bestelako ondorioak aurkituko ditugu. Lehen-lehenik, eragina aitortzen dio inguruari bere poesia sortzeko orduan eta sena egiteko unean:

"nik. hemen azaltzen ditudan izkribuak

honelakoak izango ote ziren, 
nire inguruko mendi, euri ta haizeen,

bizi naizen herriaren barruan

bizi ez banintzen?"

(ITB, amaiur)

Bigarrenik, izadiarekiko lotura bilatzen da. 1973. urtean argitaraturiko liburu batean, Sniderrek tribuari buruz hitz egiten zuen, tribuaren barnean gizakiak, animaliak eta izadia oro sartzen du :

Gizonezkoak, emakumezkoak, haurrak, ortze, haize eta hodei, zuhaitz, ur, animali eta belarren konpainian maitasun eta jakinduriaren bide eternala jarraitzeko esperantzan zaudeten guztiok, zuok zarete tribua. (1973: 215)

Horregatik, estutasun handia zegoelako gizakiaren eta izadiaren artean, izadiarekin elkarrizketan hasi behar da. Roel Van Duin deituriko idazle bat zuhaitzekin mintzo zen: "Saiatu naiz parkeko zuhaitzekin - irribarre egin nahi baduzue- hitz egiten. Hasieran, ez zuten gauza handirik esaten, baina, azkenerako, eztabaidatu egiten genuen." Roel Van Duin-en antzera Artzck ere izadiaren mintzoa entzun eta izadiarekin mintzo da:

"barkatu

karkar, muzker, sagutzar

bale, har, izai, zikiro xarmagarriak

barka nezazute. [...]

horretara zerk bultza nauen

inork egitekotan

zuek konprenituko duzutelakoan nago."

Artzek, azkenez, maitasuna eta izadia parekatu egin ditu: maitasunaren antzera sartzen da izadia berarengan eta batasun kosmiko batera heltzen dira, maitasunean ere beste pertsonarekin bat izatera heltzen den bezalatsu:

\author{
"ez dakit garbi noiz \\ bainan egunsentiarekin \\ izango zen \\ Baztango bazterrak \\ isilka \\ nere logelan hasi ziren \\ hasi ziren
}


sartzen eta sortzen. [...]

\section{Baztango lurrean \\ Baztan baitan \\ Baztan izan nintzen."}

(LGA, 42)

Paisaia, izadia, poetarengan barneratzen da eta poetak nortasuna aldatu egin du. Baina, aldaketa kosmikoak beste joerak ere baditu, eta jakinduria izadian aurkitzen dela baietsi du. Jakinduria Egiara heltzeko bidea da, eta bere poetikan askotan aipatu du Artzek, Egia agertzea dela bere poesiaren azken puntua.

"oi banintz...

izan

lurraren erraietan dabilen erro izarrak erraietan dituen haizea...

oi baneki...

jakin,

kea eta errautsa izaten

sua

sugaia

dakidanean

naizenean

ez dut beste parabisuren beharrik ukanen."

(LGA, 65)

Poema honetan laburtzen da idazlearen joera panteista, nortasuna eta izadia, izan eta jakin, bat egiten diren puntuan. Artzeren poesia guztia autoanalisia da, bere izaera eta jakinduriaren bila.

Orain arte ikusi ditugun ertz guztiak ispilu baten zatiak balira, kontrakulturaren garrantzi handikoa den transzendentziaren bidean jarri gaituzte. Orain arte, Lurra izarrez aipatu ez badugu, izan da transzendentzia bidea nabarmenen liburu horretan aurkitzen delako. Agian, horregatik da Artzeren libururik tradizionalena, bidean gora egiten duelako autoanalisian bere izaeraren bila. 


\section{Transzendentzia. Orientalismoa.}

Lehenago ikusi dugu kontrakulturak balioen eransketa adierazten duela, baina, ez duela alternatiba bat sortzen; utopia bada, baina, ez du gizartea aldarazten. Kontrakultura zehazki aztertu duen Maffi-k, adibidez, honela deskribatzen du fenomenoa:

Hirurogei urteotako underground-ak banaketa bitxia agertzen du : partehartzerik ezaren, iraultza estetiko-psikologiko-psikodelikoaren, askatasun pertsonalaren, gizartetik urrunketaren, barne eta kanpo-esperientzien bilakaeraren, bakezaletasunaren, irrazionaltasunaren eta mistizismoaren armez sorturikoa: ez indarrik, ez gezurrik, ez norgehiagokorik, ez teknologiarik, ez dagoen mundu propioa sortzeko borondate indartsurik: deshumanizazioaren eta gizatasun ezaren sintoma - barbaroak sorturiko desadostasuna- haien aurka benetako borroka baino gehiago." (1975: 26-7)

Balioen faltaz norabiderik gabe geratu bada gizakia, nortasun krisiaren agerbidea bada joera kulturala, garbi dago urteak aurrera doazen neurrian, nolabaiteko irtenbidea eman behar zaiola bizitzari. Nietzschek adierazi zuen Jainkoa hil egin zela, gaur egun gizakia ere hilik dagoela nabaritzen da, gizarteak - gizarte ofizialak- ez dio baliorik eskaintzen. "Alienazioaren aurrean", bere onetik aterea den gizakiaren aurrean, utopiaren beharrak norabidea eskatzen du.

Maffi-k berak, Estatu Batuetako zinema kritiko batek eraturiko eskematxo baten berri ematen du. Guk adierazi nahi dugunerako oso erabilgarria gertatuko dena. Aipaturiko kritiko honck kontrakulturaren zinema hiru ataletan banatzen du:

1. "Kritika sozialeko eta protestako filmak", gure munduko alderdi errepresiboen eta artifizialen aurka.

2. "Askatasun filmak", irudimen anarkikoaren bidez, gizarteak ustelduriko gabeko giza-izpirituan ahalbideak erakusten dituena. [...]

3. "Filme mitikoak", gure hutsune arrazionalista betetzeko eskakizunaren bidez, mito munduan diren barne munduak sortzen dituztenak. (1975: 250-252)

Hiru alderdion garapen joera kontuan hartzen badugu, Artzeren poesiaren nondik-norakoa adierazteko formula ezin hobea izango dugu.

Bere poesia hasi protestarekin hasten da, inguruan duen gizartea gaitzetsiz, fariseismoaren, industriaren, gizarte mekanikoaren, errebeldia faltaren, kalte askoren salaketa eginez; eta horrela sortuko da, etenduraz Isturitzetik Tolosan barru. 
Giza balio faltsuen salaketa egin ondoren, Artzek bere askatasun mundua sortzen saiatzen da Laino guztien azpitik eta sasi guz.tien gainetik liburuetan : askatasuna, maitasuna, elkartasuna, ekologia izango dira barne-analisian saiatzen den poetarentzat.

Alde mitikoa falta da. Eta alde mitiko hori transzendentziaren bidetik etorriko da. Artzeren mito nagusiak ere kontrakulturaren eremuetan kokatzen dira: transzendentzia nahia, ekialdeko erlijioen eragina.

Transzendentzia gogoaz lehenago ere hitz egin dugu. Irrazionalismoak bultzatzen du transzendentziara kontrakulturaren erara sorturiko gizartea. Arrazoiaren ukazioan, bada alde bat azpimarragarria dena : arinegi bizi garenez, denbora lotu egin behar da, garaiko denboratik irten, abiadak arreta gauza askotan jartzera behartzen baitu, eta barne denbora sortu behar du idazleak.

Alde honetatik Artzeren poesia, poesia hausnarkorra da, jakituria eta egiaren bila. Ikusi dugu aurreko ataleko azken zitan nola jakitea eta izatea parekatzen dituen poetak, eta nortasuna eta jakinduria lortzea paradisuarekin identifikatzen duen.

"dakidanean

naizenean

ez dut beste parabisuren beharrik ikusten"

Hausnarketaren joera areagotu egin da bere liburu berrian, eta Ortzia lorez, Lurra izarrez joeraren apologia izango da:

"Dakienak badaki

nora dijoan jakiteko

behar duela

nondik datorren jakin;

nondik datorren

nora dijoan jakin

non dagoen jakingo badu;

etorri aurretik ikusi zuenaz orhoitu, joan ondoren hura bera ikusiko bait du. [...] 
Dakienak ba daki,

ez dakienak baleki...

orduan, bai ederki."

$(\mathrm{OL}, 44)$

Azken batean, poetak badaki hitza eta isiltasuna, behar-beharrezkoak direla prozesu honetan:

\author{
"Hitzaren bidez sortu du Jainkoak \\ dakusagun mundua, \\ eta isiltasunaren bidez, \\ ez dakusagun mundua"
}

(OL, 40)

"Ez dakusagun" mundura heltzeko, beraz, isiltasuna beharrezkoa da, hausnarketa, alegia. Munduak eta gizarteak eskaintzen dituzten arinkeria eta harrabotsa alboratu behar genituzke eta barne-joeran sakondu zer garen jakiteko. Isiltasuna transzendentzia bide bihurtu du Artzek erroetara joateko bide.

Kontrakulturak arrazionalismoaren ukazioa egin zuenean, ekialdeko filosofiara eta erlijioetara jo zuen jakinduriaren bila. Ekialdeko joera nabarmentzen hasi zen 50. hamarkadaren ondoren. Mendebaldean, ordea, azaleko aldeak onartzen dira, eta denak nahas-nahas, sinkretismoaren joera agertzen delarik nagusi :

Joera hori, oncloko jakituriak baino usuago, alde "folklorikotik" sortzen da. Eta horregatik, oso sinkretikoa da: Buda, Shiva, Mahoma, Jesus... erraztasun harrigarriz biltzen dira. Baina, denak datoz helburu batekin; beharrizan bateri atxikia: kontzientzia zabaldu eta bizitza berria lortu.

Horregatik, onartzen da munduaren joera zientifikoa eta ezagutza arrazionalaren nagusitasuna zalantzan jartzen duen tradizioa, analisiak esperientzia inefablean, isiltasunean bukatu behar duela defendatzen duen tradizioa. (López Ibarrondo 1991: 190)

Ekialdeko joerak, Mendebaldekoaren ukazioa den neurrian, eragin handia izan du literatura eta artean:

Beste iradokizun batzuk gizakiaz, bere bizitzaz eta bere sormen lanaz ulermen desberdina duten zibilizazioetatik datoz:

Ekialdea : ni-zenaren ni-guztiaren, logikaren ukazioaren (edo a-logikotasunaren), bere zentzutik - ordenik ez, gauzen joanaz eta ezinasmatuaren baieztapenaren bidez, eragin handiz - filtratua eta manipulatua izan zen, hala ere izan zuen eragina beat poeten artean (Ginsberg, Kerouac, eta poeta-ikerle ziren Gary Synder eta Alan Wattsengan), abangoardiako musikarien artean (John Cagegan), eta berrogei eta berrogei eta hamar urteen arteko arte amerikarrean." (Maffi 1975 1975: 35) 
Hiru joera omen dira nagusiak Ekialdeko filosofia eta erlijioen artean: yoga, taoa eta "zen" a. López Ibarrondok deskribatzen duenez:

Yoga gogoa pentsakizun guztiz hustuteko erabiltzen da, zeren pentsakizunak gogoa higiarazi egiten du, eta horrela ezin du gauzak zuzen adierazi. [...]

Ezagutza bide gisa, taoak garrantzi handia du gizakiaren eremuan, zeren izadian sartzen irakasten baitio, bere gorputzeko erritmoak zainduz, eta gizartearen eremuan, zeren dualismoak eta gizadiaren eta izadiaren arteko borrokak sorturiko krisialdi ekologikoa konpontzen lagundu baitezake. [...]

"Zen" filosofiak ez du ukatzen errealitatearen ikuspegi zientifikoa, baina, litekeen bakarra ez dela dio. Gogoak, "zen" aren arabera, ezin lezake errealitatea ulertu, ezin du hartara heldu, giza-izaera osoa ez badu ulertzen. (López Ibarrondo 1991: 190-193)

Artzeren poesiara itzultzen badugu arreta, eta hiru arlo horretan kokatu behar poetaren lana, gehien baten taoismoaren barruan ikusiko genuke bere lana. Hiru arrazoi leudeke horrela jokatzeko: lehena, ying eta yang-aren eragina bere lanean:

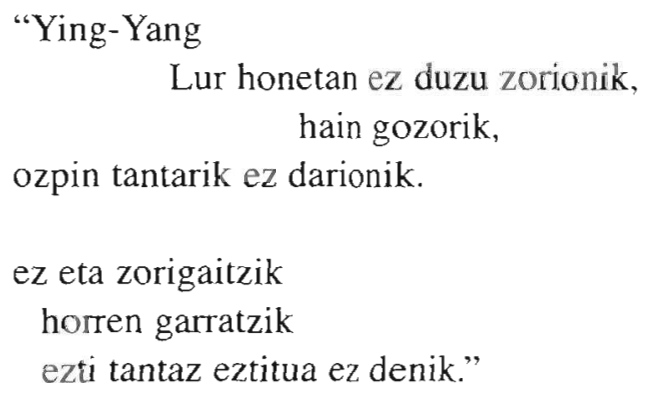

(OL, 95)

Bigarrenez, dualismoaren batuketaz hitz egiten digu poetak liburuaren izenburutik bertatik ere. Ortzia lorez ikustea eta lurra izarrez estaltzea oximorona eraikitzea litzateke, aurkarien batuketa, aurkakoen bilketaz osotasuna lortzea eta egokitasun idealera heltzea. Aurkakoen bilketa horretan berebiziko garrantzia du "Androginoa" ren gaiak (OL, 33), hain zuzen Artzek adierazi duelako sexuaren arteko banaketa gertakizun historikoa dela. Dirudienez, garai idealean sexu biak baturik ziren eta batuketa pentsatzea garai ideal horretara heltzea litzateke.

Hirugarrenez, pertsona eta izadiaren arteko joera legoke, gorago ikusi dugun moduan. Gehitu dezakegu literaturaren historian ezaguna den beste datu bat ere. Espainian gehien zabaldu zen ideologia Taoismoa izan zen 
Bartzelonan egindako Tao te King-en argitarapenaren bidez.

Ekialde-zaletasun hori, Artzeren kasuan behintzat, beste zerbait hedatuago eta zabalduago baten adibide izango litzateke. Hain zuzen ere, Ortzia lorez liburuak ez du soilik ekialde zaletasuna agerizen. Artzerengan ere sinkretismoa da nagusi:

\author{
"On! XIVÂya namah! \\ agur zuri ekialdeko Sri XANKARATXARYA, \\ "Bakea sortzen duen Gidaria" \\ agur, zuei, ekialde urruneko TXOANG-TXE, \\ Tibetar MILAREPA, Japoniako MATSUD BAXO; \\ agur, zuri, ekialde hurbileko Rabbi MOXE BEN LEON; \\ orobat zuri, Arabiar Xeih AHMAD AL-'ALAWI. [...] \\ agur, zuei, itzalalde urruneko Siux lakotadunak, \\ MEHAKA SAPA, "Altze Beltza" eta \\ TAXUNKO WITKO, "Zaldi Zoro".
}

$(\mathrm{OL}, 156)$

Kristo, Buda, Mahoma bildurik. Ekialdea eta Itzalaldeko Sioux lakotak: primitibismoa, mendebaldeko kulturaren ukazioan.

Lautadetako indioen presentziak ez gaitu harritu behar. Estatu Batuetako egoera originaltzat eurak baititugu.

1977. urtean Ajoblanco aldizkariak Arreba lurra izenburu pean, benetakoa edo apokrifoa den testu bat argitaratzen du. Dirudienez, lautadetako indioen filosofia agertzen duen testu eder bat da. Bertan izadiaren eta gizadiaren artean diren loturak aztertzen dira poetikotasun handiz. Ondorio gisa, hauxe azpimarratuko genuke:

Hauxe dakigu: gizona ez da lurraren jabe, lurra da gizonaren jabe. Hauxe dakigu. Dena dago lotua. Familia batzen duen odola legez. Dena dago lotua.

Lurrari gertatzen zaion guztia, gertatuko zaio lurraren seme-alabei. Gizakiak ez zuen bizitzako oihala ehundu; hari bat besterik ez da. Oihalarekin egiten duena, bere buruari egiten dio.

Badakigu azal zuriak, agian, noizbait ulertuko duena: gure Jainkoa eta eurena Jainko bera da. Zuek pentsa dezakezue orain Jainkoa zuena dela, gure lurren jabe izan nahi duzuen moduan, baina, ez da horrela. Gizaki guztien Jainkoa da eta bere errukia denengana berdin heltzen da. 
Jainko bera da gizaki guztientzat hori eta Artzeren esaldiak:

"Eguzki berak gaitu jotzen, Ilhargi berak ferekatzen zuek eta gu."

ez daude urrun. Alderantziz, oso hurbil daude.

XIX. mendetik hasita Europa osoan egon da artista eta pintoreen artean ihes egiteko gogo eta joera handia. Europako hiri nagusi eta industrialak sormen bizitzarako toki kaltegarri izaki, geroztik beti izan da primitibotasuna bilatzeko joera. Baudelaire-k egin zuen bidaia paradisu garbiaren bila eta primitibotasunaren eta paradisuren profeta bihurtu zen bere artea. Gizarte zientifikotik eta teknologikotik idealismoak XIX. mendean egiten duen urrunke$\tan$, aurki dezakegu horren arrazoia. Idealismoa materialismoari kontrajartzen zaio; subjektibismoa, objetibismoari ; intuizioa, zientziari ; ideala, positibismoari ; eskuzabaltasuna, diruari ; poeta, burgesari.

Tradizio luze horretan Europako egoeraren beste aurpegia da primitiboek, beste kulturek erakusten dutena. Ez omen da haiena gurea bezain kultura neurotikoa. Bakea, gentza, garbitasuna bizi dituzte. Zoriona. Eta zoriona ez bada, guk ezagutzen ez dugun jakituria dute.

Gauzak era sinplean azaldurik badaude ere, gauzak horrela ulertzeko modua nahiko zabalik dago gaur egun ere. Kontrakulturaren garaietan bizitza "naturala" hiriak utzi eta larrera itzultzeko mugimenduak izan ziren, izadiarekin komunikatzeko asmoz.

Kontrakulturaren ikertzaile eta historiagile den Maffi-k honela azaldu du arazoa :

Beste zibilizazio horiek, [Ekialdeko gizarteak, eta Hego zein Ipar Amerikako indioen kulturak] Gizaki Naturala, kutsatu gabekoa, izadiarekin lotua deskribatzen dute eta, gainera, ekintza ez arrazionala, harrigarri-mitikoa, lehen gotorleku ingenuo gisa, teknologia agorrari kontrajarriko zaiona. (1977: 36)

Mendebaldeko arrazionalismo eta positibismoaren ukazioak industrialismoaren eta postindustrialismoarenak, teknologiarenak eta zibernetikarenak bat-batean daramate irrazionalismora, mistizismora, giza-erlijiora. (1977: 45) 
Gizarteari eta teknologiari, eguneroko bizitza historiko, arrunt, kolorgeari aurre egin: horixe da lehenik bilatzen dena. Erlijioan beste horrenbeste gertatzen da. Ez da Eliza -gizartea- onartzen, Kristoren -gizakiaren- irudiak, lehen iraultzaile gisa, indarra duen artean.

Gizarte primitiboek badute beste abantailarik. Ez dira bakarrik urrunak eta orekatuak (beti ere hemendik begiratuta): urteak dituzte, agortezinak dirudite; betikoak, jakinduria betekoak, jakinduriaz hornitua amesten dugun bezala, edozein tributako agurea.

Horixe! Agureak (edo atsoak) dira, aitonak eta amonak jakinduriaz beteak.

Jakinduriak egia bilatzen du; neoplatonikoen eta idealisten antzera. Artzek ere egia eta edertasuna lotzen ditu:

"Bi punturen artean

zein da biderik laburrena?

Biderik ederrena!

Eta zein da biderik ederrena?

Egiara daramana."

Egiara, eta era berean edertasunera, daraman bidean Artzek herri desberdinen jakituria bildu du. Testuetan sinkretismo handia nabaritzen da alde horretan. Bibliako zatiak aipatzen dira:

"Ezagutuko duzue Egia,

eta Egiak askatuko zaituzte."

Ebanjelioko zatiak zein Testamentu Zaharreko pasarteak; Taoismoa presente dago Ying-yang-en agerpenarekin :

"Ez da larrosarikan arantzarik gabe...

ezta arantzarikan ere larrosarik gabe." 
Basamortuko Tuareg-en errefrau batek, batasun hari gisa erabili du poetak, behin eta berriro errepikatzen den ritornello gisa:

"Edan ura gizon egiteko,

har eguzkia indartzeko."

(OL, 103,119)

Indiako Veda-k oreka unibertsalaren oreka emango diote idazleari:

"Eder zaizkit ametsak!

eder, sua eta ura,

ta haizea eta lurra!

haietaz orhatuak bait dira hauek,

eta eder, ederretan eder,

hauen erdian errotuz

haien gainetik

loratzen den bihotza!"

(OL, 168)

Arabiarrek erakutsiko diote lotura handia dagoela pertsonaren eta munduaren artean, eta bere poesiaren gune izango den esaldia oparitu diote:

"Gizon haundia da mundua, eta mundu ttikia gizona."

$(\mathrm{OL}, 124)$

Eta horiekin batera:

"agur, zuei, itzalalde urruneko Siux lakotadunak,

MEHAKA SAPA, "Altze Beltza" eta

TAXUNKO WITKO, "Zaldi Zoro".

$(\mathrm{OL}, 156)$

Herri guztion aipamenak funtzio bi ditu: gorago ikusi dugunez, gizarte teknologikoaren aurrean beste gizarte "naturalagoa" erakutsi nahi digu idazleak. Kontrakulturak sortu dituen mitoen aurrean, eta bultzatu dituen gehiegikerien aurrean, bide sakonagoa, errotuagoa, "egiazkoa" erakutsi nahi digu idazleak.

Garai batean gauzen koloreak eta itxurak besterik ez nian ikusten; orain, berriz, gauzen barru-barruko muina ikusten hasi nauk. Horixe duk. Ilunaldi latz baten ondoren etorri duk hau [...]. Inguruak agintzen zian lehen gehienbat ni baitan: ingurua huen indar eraginkorra. Alderantziz dela orain, esango niake, hau duk kanpotik barrura ordez, barrutik kanpora dihardudala. (Mollarri 1982) 
Honela mintzatzen zitzaion Artze elkarrizketa batean kazetariari. Azpimarragarriak dira hemen hainbat hitz: ilunaldia igaro izana, lehenik. Ikuskizunaren aldaketa gero. Nitasuna barnerantz begira jarri da, eta sakontasunak agintzen du orain, modernitatearen azalari uko eta kritika eginik, primitibismora itzultzea modernitatearen jite errotua bada ere.

Bigarrenez, kontrakulturak agertu duen krisi-balorearen aurrean erantzuna osatu nahi du. Zein erantzun?

Testuak irakurriz gero, 173. orrialdean idazten denak kontzeptuak argituko dizkigu:

"Itzarririk, Ametsetan, Lo sakonean, Areago."

Lo sakonean baino sakonago, areago dagoen izaera agertu nahi du Artzek.

Hasi anaidi unibertsalarekin hasiko litzateke idazlea; neurri batean, kanpo aldean, edo inguruan, nahi bada:

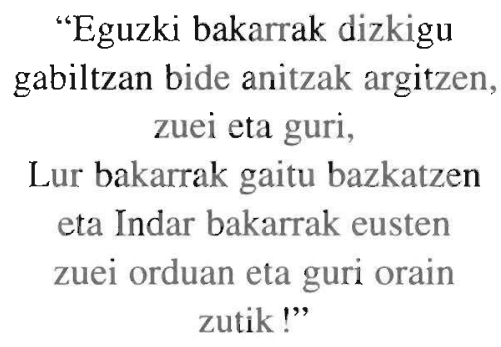

(OL, 156)

Anaidi unibertsalaren proposamena Vietnam-go guduak jo duen belaunaldi baten garrasia da bakezaletasunaren alde eta militarismoaren aurka. Baina, beste aldetik, politika berria eraikitzeko modua da. Frantziako Iraultzak sortu zuen hirutasunetik: Askatasuna, Berdintasuna, Anaitasuna, azkena da praktikara eraman ez den bakarra. Askatasuna gizarte liberaletan eta Berdintasuna gizarte komunistetan eragina izan ondoren.

Anaidi idealeko ideiek erakusten diote zein den biderik ederrena, egiara daramana, hain zuzen ere. Badu bide horrek zerikusirik Indiako tradiziotik hartuz egokitu duen bertsoarekin :

"Iratzarrik. Ametsetan. Lo sakonean. Areago."

Esaldi horrek idealaren aurrean jarri gaitu. Idealera, eta hau ere joera ezaguna da, heltzeko musikak, eta musikaren erritmoak zerikusi handia du, planeten birak musika egiten baitu, eta erritmo berdinez ari da mundu horietako musika eta mundu hartakoa. 


\section{"Urruna dugu kantu hau,}

eta hurbila, hurbilik bada:

urrunena, urrunetan,

hurbilena, hurbiletan,

izar guztiek dutenez lotkarri

bihotz muinean duguna iturri :

kanturik haundiena

tokirik ttikienean...

kantu bakarra."

$(\mathrm{OL}, 182)$

Kantu bakar horrek garamatza ametsen mundura, desioenera, idealena: beste mundu bat behar dugu, baina naturala, kontrakulturaren gehiegikeriarik gabe. Ametsaren bila doa, pertsonaren gogoa:

"Gauero itzaltzen da

gizakumea,

goizero bizten,

eta bien bitartean

amets du egiten.

Goizero bizten da, gauero itzaltzen, eta bien bitartean

amets bat du bizitzen."

Ametsa bizi du eta ametsak bizi du pertsona, ez du bakean uzten, piztu du, bizitzan jarri du, bizitzara eraman. Ametsak eta Erromantizismoak luze hitz egin zuen gai honetaz, idealera darama, baina, poetaren bihotzetik igaroz:

"bihotzean bizi den "Nor" hori, halaber...

mundu denak batuta baino haundiagoa du."

$(\mathrm{OL}, 182)$ 
Bihotzean sakonduz, bihotzean bide eginez, Maitasuna ageri da. Esanguratsua liteke azpimarratzea Ortzia lorez liburuko azken aldea maita sun-kantu oparoa dela.

Maitasuna da bide :
"Izan zakizkit

ate,

maite,

izan nakizun bide."

$(\mathrm{OL}, 211)$

dio poetak eta liburua hiru hitz horiekin bukatzen du:

$$
\begin{gathered}
\text { "ate, } \\
\text { maite, } \\
\text { bide!" }
\end{gathered}
$$

(OL, 213)

Maitasuna ate eta bide ideal guztiak nahi duen heriotzaren aurkako guduan garaile izateko, hau baita ideal guztien helburua: existentziaren gainetik izatea :

"Heriotza bezain indartsua bait da Maitasuna" aipatuko du poetak, ondoriora heltzeko:

"Nork maita lezake heriotzarik ez balitz...?

Eta maitasunik gabe, nor bizi daiteke nork heriotza gaindi maitasunik gabe."

Egia, Ederra, Ametsa, hirurak doaz bide berdinetik maitasunaren hegalpean kokatzera, eta hauxe da Artzek eman duen bidearen berria. 


\section{Bibliografia}

LOPEZ ADAN, Emilio. 1996. "Rikardo Arregiren garaiko mogimendu politikosozialak" in TORREALDAY; Joan Mari (zuz.) : Rikardo Arregi. Gizona eta Garaia. Andoain. 199-255.

LÓPEZ IBARRONDO, Andrés. 1991. La contracultura en España en la segunda mitad de la decada de los setenta, Eusko Jaurlaritzaren argitalpen zerbitzu nagusia, 97-274.

FROMM. 1973. Ensayos sobre el Apokalipsis, Kairós, Bartzelona.

IZTUETA, P. 1996. "Euskal Eliza eta seminarioak Frankismoan". Torrealday; Joan Mari (zuz.): Rikardo Arregi. Gizona eta Garaia. Andoain. 121-197.

Donostia.

RACIONERO. 1977. Filosofias del underground. Anagrama. Bartzelona.

MELVILLE, K. 1976-2. Las comunas en la contracultura, Kairós, Bartzelona.

MAFFI, M. 1975. La cultura underground, Anagrama, Baitzelona.

Oharra: lan hau 1998. urtearen hasieran idatzi zen. Ez dira beraz erabili berriki agertu diren Belen Oronozen: Gazteri berria, Kantagintza berria eta Amaia Iturbideren B. Gandiaga, J.A. Artze eta X. Leteren poemagintza lanak.

Lan hau Euskal Herriko Unibertsitateak eskainitako hb $136 / 99$ ikerketa proiektuari luzaturiko laguntzari esker moldatu da. 